Editorial

\title{
The zika conundrum
}

\section{Editorial}

It has been a very difficult 2015 for Brazilian citizens, amid one of ebay most severe economic crisis since 1992; moral and ethical scandals emerging from within the government- who is also submerged in corruption scandals and is constantly losing political battles- in time, this context might even lead to an impeachment of our president; and last but not least, political agendas that divided the country in left and right wing protesters, both urging their sides to engage in open battle. Adding to the dreary picture, and as a derivative of the previous facts, hospitals in major cities are now facing the lack of federal and state funds with both despair and skepticism. Most units historically dealt with overflowing patients with little or no rooms available to host them. This is, in itself, grave enough to raise concerns, even to the most naïve of us, but this is, unfortunately, not all. A recent accident flooded cities after a dam broke loose, thousands were instantly homeless and the water, used to dump rejects of a mining company, swept the countryside contaminating rivers and its surroundings, this is particularly important because the populations affected by this tragedy are now deprived of potable water, forcing each and everyone to seek other means of obtaining and stockpiling water on their own. Several reports have found that events such as droughts (which are comparable here due the lack of clean water) contribute significantly to infections, The past three years, Brazilians have watched ever raising numbers of infections due to Dengue, the disease is now one of the most important public health concerns since Yellow Fever back in 1900-15. The numbers for Dengue virus from the Ministry of Heath are alarming, until November of the last year there were 950 thousand notified cases, out of which 644,202 were confirmed with 19,530 cases being autochthonous.

Now Brazil faces another complication, the arthropod-borne infection caused by the Zika virus is spreading quickly throughout the Americas, the first cases were reported in February, 2015 mainly in Bahia, Maranhao, Paraiba, Pernambuco and Piaui, states of the northeast of the country. What initially was thought to be a self limited mild disease soon escalated to cause panic nationwide, It spread quickly - as estimates of the government show, since a routine diagnostic is not available at this point and the virus is closely related to Dengue viruses this is still under development. On top of that there seems to be an association between the viral infection and cases of microcephaly, which also rose to disproportional levels countrywide and appeared to be distributed among the states with higher incidence
Volume 3 Issue 2 - 2016

The zika conundrum

State University of São Paulo, Zika Task Force, Brazil

Correspondence: Daniel Ferreira de Lima Neto, State University of São Paulo, Zika Task Force, Brazil,Tel +5511943431979, Email danielviro@gmail.com

Received: January 12, 2016 | Published: January 28, 2016

of the infection caused by Zika. As of January $8^{\text {th }}$ there are now 3.174 confirmed cases of this condition over the nation, prompting doctors to recommend women not to get pregnant for the next year, delaying planned births to a maximum.

Now, all things considered, it is rather complicated not to worry for Brazil and, if the projections verify themselves, for the world. Such an association between and arbovirus and a newborn disease bares disturbing implications for pregnancy in developing countries, those of which have historically presented with higher birth rates and young populations. Regions in the northeast were the water supply was affected by the Samarco/Vale/BHP disaster will make personal, mostly in house reserves of it, the authorities are expecting to see a rise in mosquito populations in those areas. Corruption scandals and non-effective politics now drive the outcomes of thousands of children born with this condition, health authorities are making the best they can with the little they get. Several groups of scientists around the country have joined in task forces to tackle the problem, and they were so efficient about it that members of the group that fought Ebola in Guine were brought to Sao Paulo to train virologists from all over the country, on the other hand though regulatory agencies still hold on to reagents at the border due to anachronistic procedures, a kind of bureaucracy incompatible with the job at hand and apparently disconnected from the tough reality that the country endures today.

Brazilians now have little time to solve for all of these variables, and the more the country waits the more viruses/variables come into play as researchers are also considering Mayaro and Oropouche virus as possible links to the condition. Science is doing its job, the country must join in and share the load. 